\title{
A Question of Identities: Jewish Italian Immigrants in New York During and After War World II
}

\author{
Cristina M. Bettin \\ Ben Gurion University of the Negev, Israel
}

\begin{abstract}
There are many studies on Italian and Jewish immigration in the United States, mainly based on socio-demographic statistics, the theme of exile, Fascist anti-Semitism or ethnic conflicts. Many of these researches focus primarily on Jewish or Italians, but rarely address at Italian Jews as a whole, and, in their relation with Italian American and Jews. One of the reasons of this paucity of studies, might be the little number of Italian Jews who immigrated to the United States, especially in New York in the 1930s and 1940s, that drove several scholars not to pay really attention to this tiny group in ignoring their presence. Thus, this article aims to investigate through some memoirs, interviews and autobiographies the life of Italian Jews who were living in New York and the Metropolitan area during and after War World II, with particular emphasis to those who were born there in these years and their formation of an American identity. This essay will also clarify the role of memory and "nostalgia” in an Italian identity—above all an Italian Jewish identity—which made Italian Jews a unique group and a minority within a minority.
\end{abstract}

Keywords: Italian Jews, anti-Semitism, emigration, Jewish identity, Italian identity

Italy is traditionally a country of emigration and at the end of the 19th century, emigration became a mass phenomenon. Almost seven hundred thousand Italians arrived in the United States from 1890-1900, two thirds of whom were men. Many of them were from rural southern communities, unskilled and with very little education. There were various reasons for their emigration, including disease and starvation. ${ }^{1}$ Italian emigrants settled mostly in New York, in a community made up of people from their native village or region, so that relatives or friends could provide shelter and assistance.

During 1900-1914, Italian emigration reached its peak of more than two million. Once World War I was underway (from 1915-1918), emigration ceased, but in the following years thousands of Italians left Italy. Following the United States immigration acts of 1921 and 1924, emigration from Italy declined. Fascism — which was hostile to emigration—and World War II almost eliminated emigration, but it increased again at the end of the war.

Cristina M. Bettin, Ph.D., Senior Lecturer and Researcher, Department of Foreign Literatures \& Linguistics, Ben-Gurion University of the Negev.

Correspondence concerning this article should be addressed to Cristina M. Bettin, P.O.B. 653, Beer-Sheva 84105, Israel.

${ }^{1}$ At the end of the nineteenth and beginning of the twentieth century, food had become the biggest cost for an Italian family. Many peasant families spent about $75 \%$ of their money on food, which despite the high cost, did not contain enough nutrition to sustain a person. To make matters worse, the agricultural system of Italy was not modernized, methods of production were primitive, and taxes were oppressive, and there was little hope of improving the situation. Furthermore, during this time Italian agriculture was hurt by the increasing number of products from America that invaded Italian markets. The price of wheat and other products fell. There was no alternative than to emigrate. 


\section{Italian Jews Immigrants in the United States}

Italian Jews began arriving in the United States in 1930. It is very difficult to determine how many Italian Jews came to the United States because many of them travelled by themselves as single families, with no support from any organization or group. Only a few Jews were supported by the Hebrew Immigrant Aid Society (HIAS), which, after War World II, assisted thousands of Jews to leave a devastated Europe and to find new homes and build new lives in freedom. Working in the displaced-persons camps, HIAS helped survivors locate family in the United States, secure visas, and travel to their new homeland. ${ }^{2}$ According to HIAS's data, the number of Italian Jews, defined as immigrant aliens of the Hebrew race, admitted to the Unites States from June 30, 1935 to 1938, was precisely 109; in 1935, 13 were admitted; in 1936, 28; in 1937, 78; and in 1938, 30. In addition, they were 55 Italian Jews who were considered non-immigrant aliens of the Hebrew race admitted for temporary stay in the United States. As in the case of the permanent immigrants, their number, though small, increased from 1935 to 1938: in 1935, five Italian Jews were permitted temporary residence; in 1936, this doubled to ten; in 1937, 13; and in 1938, 23. ${ }^{3}$ There were, however, more Italian Jews who wanted to emigrate, but were unable to. With the Racial Legislation Laws of 1938, Italian Jews, in particular youths of military age, were no longer granted passports for emigration, as they were of considerable valuable to the government in the event of war. In the 1930s, until precisely 1938, the reason for Italian Jewish emigration was prevalently ideological. Unlike the rest of the Italian population, they did not emigrate, in order to avoid starvation or disease, to look for a better life, or to "survive."

Italian Jews who emigrated in the 1930s belonged to the middle and upper classes; they were literate, skilled, and anti-fascist. When Mussolini promulgated the Legislation Racial Laws in 1938 which discriminated against Jews by no longer allowing them to work in any public ministerial office, university and so on, they decided to immigrate to a country which gave them rights and the opportunity to work and live as free individuals. It is possible to see this trough the reading of several autobiographies, memoirs, and interviews that I have had through the years with some of these Italian Jews, which immigrated in New York Metropolitan Area in the early 1940s.

One of these is the case of George Sacerdote's family. George's father, aunt, and uncle were dismissed from their jobs as engineers and medical doctors in Piedmont. As a consequence of this discrimination, they left Italy, and settled first in Switzerland, moving to France in 1939, and travelled to the United States a year later, in May 1940:

My family came, despite not having a passport valid for travel to the United States. The US consul in Lyon gave them special travel immigration documents because my father had experience in the rubber industry and there was a rubber shortage in the United States due to Japanese conquest of Malaya. My grandmother was sponsored by my uncle, who had

\footnotetext{
${ }^{2}$ After WWII, Italy was the main transit country for Jewish displaced persons who wished to leave Europe and immigrate to Palestine. In 1945, there were about 12,000 Jewish displaced persons in Italy; in a few months this rose to 30,000, as newcomers constantly replenished the places of those who left for Palestine. The camps were cared for at first by the United Nations Relief and Rehabilitation Administration (UNRRA), and later by the International Refugee Organization (IRO), with supplementary aid from the American Jewish Joint Distribution Committee (AJDC) and from the Jewish Organization for the Promotion of Education and Training (ORT), which set up workshops and trade schools to teach employment skills, and provided health facilities. AJDC supported also a Yeshiva and helped maintain kosher kitchens. The camp residents were governed by their own elected representation, the Central Committee of Liberated Jews, and by local camp committees. The closing of the camps began in 1948, when 20,000 displaced persons fled to Israel.

${ }^{3}$ Documents and data found at the archive of the Institute for Jewish Researcher (YIVO), New York, HIAS-Italy, box 14, folder 33.
} 
arrived from Paris some weeks before. When they arrived, my father was classed as an enemy alien. Therefore, he was unable to work in sensitive industries which made him virtually unemployable in his profession as an engineer. Finally, after three years, he found work in New Haven as a quality control engineer in a factory making rubber life rafts for the war effort. At the same time, my mother obtained her first serious job, teaching at Yale University. The Jewish charities were totally useless in trying to find jobs for Italian Jews who were professionals. ${ }^{4}$

Other Italian Jews had similar experiences to Sacerdote's family: the architect David Jona worked as a laborer in a scrap metal yard and later on a chicken farm, but only several years later was appointed to the faculty at Harvard University. Many Italian Jews adapted themselves and worked in different fields, completely changing their lifestyle. Only a few Italian Jews were lucky enough to find work in their field; many of these exceptions were scholars and scientists, who in the coming years would win Nobel Prizes, such as the economist Franco Modigliani, or Salvador Luria, a pioneer of molecular biology, who became the world's leading expert in the genetic structure of viruses. The nuclear physic Emilio Segre, who discovered antiprotons — a sub-atomic antiparticle — was a member of the Manhattan Project from 1943, and, together with Enrico Fermi and other Jewish immigrant scientists, developed the research for the atomic bomb. Enrico Fermi, who also won a Nobel Prize (in 1938, for his research in radioactivity and nuclear reactors), was not a Jew, and in 1938 was not yet discriminated against, unlike his Jewish wife Laura Capon. Nevertheless, he decided to immigrate to the United States, where he continued his work as a physicist. Even if the Jews who successfully managed to progress in their field were few, one thing that always distinguished Italian Jewry from the rest of the Italian population that emigrated before, during and soon after War World II, was their high level of education.

Many Jews who immigrated to the United States, or to Israel, were doctors, lawyers and university professors, such as Roberto Fano, emeritus professor of Computer Science, and the anti-Fascist Max Ascoli, who immigrated to the United States in 1931. Ascoli, who was a university professor and scholar, was one of the founders of the New School for Social Research in New York. In addition, he was a member of the anti-Fascist movement Giustizia e Liberta' (Justice and Freedom), as well as an active member of the Mazzini Society, an anti-Fascist society established in order to represent Italians and Italian-Americans in the United States. The aim of the Mazzini Society, as set out in its statute, was "to remain loyal to the tradition of the Risorgimento, in promoting the ideals of liberty and democracy upon which the Constitution of the United States is based.” 5 In order to achieve this, the Mazzini Society promoted many cultural activities amongst the wider American public, reaching further than the Italian and Italo-Americans. One of these activities was to carry out a program of democratic education, especially among Italian language groups, through lectures, radio broadcasts, meetings, press releases and the publication of the society bulletin, Nazioni Unite (United Nation). Several exiliated Italian Jews were members of this society, including Tullia Calabi Zevi, an Italian journalist and former President of the Union of the Italian Jewish communities in Italy, who directed a program for partisan fighters from the National Broadcasting Company offices in New York, and was also responsible for the biggest Italian language radio station. As she wrote in her memoirs:

Beyond our work within the Italian community, we also had to inform the more general American public of the justice of our cause. We had to prove that Italy and Fascism were not inseparable and to demonstrate that Italy's honor would be won not in defending Fascism but in fighting for its defeat and for the re-birth of democracy. We published a

\footnotetext{
${ }^{4}$ George Sacerdote, interview by the author, New York, 2011.

${ }^{5}$ See the Statute of the Mazzini Society, in Max Ascoli Archive, box 202, folder 6, Howard Gotlieb Archival Research Center, Boston University.
} 
bulletin with the title Italy Against Fascism — which caught the attention of the liberal American press including the New Republic, The Nation and the Partisan Revue as well as some of the big newspapers, like the New York Times. Our relation with the liberal American society proved to be rather positive and effective. ${ }^{6}$

I used the term exiliated rather than "immigrated," because it reflects the peculiarity of Italian Jewry and their identities as both Italian and Jewish, most accurately. For many Italian Jews, and above all for those who fled in the 1930s, their home was Italy, and leaving the country where they were born and raised was more a constraint of their anti-Fascist ideology and the rise of anti-Semitism, rather than a decision to start a new life in the United States.

In order to understand why Italian Jews had this strong feeling of Italianess and love for what they consider their "fatherland", it is necessary to look back at their history, particularly after their emancipation.

\section{Italian Jews: From Emancipation to War World II}

The history of Italian Jews, since the establishment of the first ghetto in 1516, was never uniform, and is closely related to, and intertwined with, that of their gentile neighbors. Until the 19th century, when the Italian Peninsula was unified, Italy was divided into different regions, each with its own customs, dialect (the local spoken language before Italian), and political administration. There was no homogeneous national culture, but rather various and different regional cultures, as well as people with different identities. The situation of the Jews therefore differed from region to region, with some regions being more tolerant than others:

The historical events that took place in Italy before and after the unification had both direct and indirect effects on the political status of the Jews. These events shaped not only their socio-demographic characteristics, but also their perception of being Jews in a secular country such as Italy was at the end of the nineteenth century and the beginning of the twentieth. At that time, the state religion, Catholicism, had marginal importance in this regard. Other ideals were more central than religion. In Mazzini’s terms, these were humanitarianism, love for the fatherland and liberalism. Italian Jews were no different from their gentile compatriots, and they believed in these ideals as Italians did. ${ }^{7}$

It is for this reason that many Italian Jews, even before the Edict of Emancipation of 1848 that gave civil rights to the non-Catholics, including Jews, participated in the Italian wars of independence. There is evidence, in fact, that Jews were involved in the movements that emerged after the French revolution and the first years of the 18th century, such as Carboneria and Giovine Italia. ${ }^{8}$ Indeed, sharing democratic and liberal values with the rest of the Italian population helped the Jews to find their place within Italian society and led them to be accepted as equals.

During the Risorgimento, Italian Jews did not feel that they had been admitted to a pre-existing economic social and political system. Rather, they considered themselves the creators and co-founders, together with the other Italian patriots, of something totally new. Italian Jews took an active part, then, in the construction of Italian identity. This fact is of central importance in understanding what makes Italian Judaism unique, and it also explains why Italian Jews, like their Catholics neighbors, always had a strong feeling of belonging toward Italy.

\footnotetext{
${ }_{7}^{6}$ Zevi Tulia, Ti racconto la mia storia (Milano, 2007), 41-42.

7 See Bettin Cristina, "The Role of Holy Place in Memory and Nostalgia: The Immigration of Italian Jews to Israel before and after WWII”, Forum Italicum 45, n. 2, (2011): 360.

8 The Giovane Italia (Young Italy) was the underground revolutionary organization founded by Giuseppe Mazzini in 1831, which aimed to liberate Italy from foreign oppressors and to create an independent unified republic.
} 
The significant role that Jews had in the construction of an Italian identity explains also why it is impossible to generalize the history of European Judaism, and, concepts such as: assimilation or integration of minorities groups into majority of societies. The claim of the American scholar Gerald. L. Showstock, who affirms that: Jews have always been different to other ethnic groups because they were always in Europe as a distinctive and separated minority with their own culture and identity ${ }^{9}$, could not be sustained for Italian Jews, especially following the period of the Emancipation, and onward.

From the time of the unification of Italy (1861-1870), Jews played an active part in the political and public life of the country. ${ }^{10}$ A part that has not been always linear, but had controversial too.

This active participation in fact opened a debate within the Italian Jewish communities and in the Jewish press, which constantly reported the danger of Jewish assimilation into the country, at the expense of the Jewish identity. One of the consequences of the emancipation was, in fact, a distancing of many Jews from Judaism; following the opening of the ghetto's gates, attendance fell at synagogues and Jewish education was neglected. This is why, in order to maintain their Jewish identity, from the end of the 19th and beginning of the 20th century, a group of Jews, mostly youth of the Rabbinical Colleges of Padua, Leghorn, and Florence, promoted an array of activities, such as the formation of Jewish movements, cultural societies, newspapers, and congresses, with the aim of re-birthing the Italian Judaism and keeping the Jewish identity alive. It is worth noting that Gentiles were freely admitted to all these activities, including the society Gli Amici del Giovedi' (The Friends of Thursday), that met each Thursday and hosted a group of people to discuss a variety of Jewish topics, or the Oneg Shabbat institution that held a meeting each Friday in a Jewish home to celebrate the Shabbat. ${ }^{11}$ As mentioned, it is important to stress that all the Jewish activities and movements were open to everybody, because the aim of the Italian Jews was not to isolate or to distinguish themselves as different, but rather to maintain their Jewish identity while living in a closely linked way within the Gentile society. It is this nonsectarian aspect that makes the case of Italian Jewry unique among the other Jewish communities in Europe.

\footnotetext{
${ }^{9}$ See Showstack Gerald, "Perspective in the Study of American Jewish Ethnicity”, Contemporary Jewry 11, n. 1 (1990): 77-89.

10 The most important Jew in Italian public life during the Risorgimento was Isac Artom, who served as Camillo Cavour's private secretary and chief secretary in the Italian Foreign Office and later, in 1876, as senator. In 1861, Giuseppe Finzi, together with two others Jews, was elected to serve in the first Italian Parliament, and in 1874 eleven Jews served as deputies. In 1891, Luigi Luzzati, a member of a prominent and patriotic Venetian Jewish family, served as Minister of Finance until 1892, from 1896 to 1898, and again from 1903 to 1906. From 1900 to 1903, another Jew, Leone Wollemberg, held the same position. In 1910, Luzzati was appointed Prime Minister. Other Jews, too, attained positions of power: in 1890 an irredentist journalist from Trieste, Salvatore Barzilai, the "deputato di Trieste al Parlamento Italiano" (the member of the Parliament of Trieste to the Italian Parliament), was elected to the Chamber of Deputies, where he remained for eight terms, serving in the Cabinet before and during World War I. He was a member of the Italian delegation to the Peace Conference at Versailles after the war. Treves and Modigliani served as socialist deputies for many years before, during, and after World War I. In 1888, Giuseppe Ottolenghi was elected senator. In 1902, he was appointed Italy’s first Jewish general. He was senator and later Minister of War during 1902-1903, while the Venetian Gabriele Pincherle was honorary president of the Council of State. In 1907, Ernesto Nathan was elected mayor of Rome. Leopoldo Franchetti served as a conservative senator for many years before committing suicide in despair after the Italian debacle of Caporetto. Sidney Sonnino, who was born a Jew in Pisa in 1847, but converted to Protestantism, served as Finance Minister and later as Foreign Minister. In 1906, and again from 1908 to 1910, he held the position of Prime Minister. Lodovico Mortara was Minister of Justice and Religious Cults from June 1919 to May 1920. These men were the best-known Jewish politicians, but there were many others. According to the historian Guido Bedarida, there were 24 Jewish senators in 1919. In 1923, the number rose to 24, out of a total of 406 (about 5\%), and in 1927, of a total of 352 senators, 17 were Jewish. When, at the beginning of 1919, Benito Mussolini, who was a former socialist journalist and former director of the socialist newspaper Avanti, founded the Fascist Party, he had Jewish support.” Bettin, Cristina, Italian Jews from Emancipation to Racial Laws (New York, 2010): 30-31.

${ }_{11}$ The Oneg Shabbat was an institution created in Palestine by the Jewish poet Haim Nachman Bialik, which was aimed to make the celebration of the Sabbath comprehensible to all.
} 
Jewish life after the Emancipation was like the life of the rest of the Italian population. Italian Jews lived the same lifestyles as those of other Italian citizens and they belonged to same social class.

"We [Jews] lived where we liked, we traveled as we wished, we chose the professions that we wanted", wrote Lucia Servadio Bedarida in her diaries. ${ }^{12}$ Being a Jewish child at the beginning of the 20th century, will write Carla Pekelis in her memoirs, “didn’t means nothing, because being a Jewish at that time was for me more a question of things that I did not do than things that I had to do."13.

And, although in her memoirs, she mentioned a few incidents that seem to appear as anti-Semitic ${ }^{14}$ Pekelis felt that she has never been treated like an outcast or badly by the ordinary people, contrarily to Alex, her Jewish Russian husband, that "had been raised in fear of pogroms, which has pursued his forebears for generations." 15

The same feeling seems to be shared by Edda Servi Machlin, that in her memoirs affirms that being a Jew had been for her (this until the second half of the 1930s), "only a question of heritage and religion persuasion"16. or, something that “didn't meant to much”, as Primo Levi wrote in his autobiographic book The Periodic Table, because (this until 1938 and the publication of the magazine Defense of the Race) he always considered his origin as an

almost negligible but curious fact, a small amusing anomaly, like having a crooked nose or freckles; a Jew is somebody who at Christmas does not have a tree, who should not eat salami but eats it all the same, who has learned a bit of Hebrew at thirteen and then has forgotten it. ${ }^{17}$

The same thing happened to the anti-Fascist Jew politician Vittorio Foa, that after his Bar Mitzvah forgot everything and lost all connection to religion, becoming "profoundly assimilated, a son of the French Revolution, which had assimilated the Jews." ${ }^{\prime 18}$ Or, like Giulio L. Cantoni that remembering his family in Fascist Italy, wrote that his family's contact with the Jewish community were limited to short visits to the synagogue on Yom Kippur and on Passover. "We did not belong to any Jewish organization and were not following Jewish dietary or any other religious or cultural tradition. My parents' friends were predominantly non-Jewish, and, as far as I can remember, at home we did not engage in serious discussions of Jewish problems." ${ }^{19}$

Also for Italian historian Dan Vittorio Segre, Fascism, was,

a natural form of existence... I lived for 16 years in Fascist Italy. Those years of Italian life were for me an existence so regular, normal and carefree, so devoid of events, that I would find it very difficult to say what was special about Fascism... and, I don’t remember either in school or outside, one single occasion when I felt uneasy because I was Jew. ${ }^{20}$

\footnotetext{
12 Bedarida Servadio Lucia "Reflection on an Italian Jewish Life”, The Most Ancient of Minorities—The Jews of Italy (Westport, 2002), 353.

13 Pekelis Carla, My version of the Facts (Evanston, 2004), 22.

14 It is possible to understand this when her friend Maria commented on Pekelis being a Jew "I like you Carla; no one would guess that you are Jewish" or when she "only got a six.” in a composition which she was asked to write about the Church, Pekelis, Ibid., 22-23.

15 Ibid., 53.

${ }^{16}$ Servi Machlin Edda, Child of the Ghetto-Coming of Age in Fascist Italy: 1926-1946. A Memoir (Croton-on-Hudson, 1995), 70.

17 Levi Primo, The Periodic Table (Great Britain, 1985), 35-36.

${ }_{18}$ Vittorio Foa in Stille Alexander, Benevolence and Betrayal: Five Italian Jewish Families Under Fascism (London, 1993$), 95$.

${ }^{19}$ Cantoni Giulio, From Milano to New York. By Way of Hell. Fascism and the Odyssey of a Young Italian Jew (Lincoln, 2000), 53.

${ }^{20}$ Segre Dan Vittorio, Memoirs of a Fortunate Jew. An Italian Story (Chicago, 1985), 46.
} 
Italian Jewish integration to Italy, strong nationalism and feeling of belongings to the Peninsula, it is expressed and depicted in almost all Jewish biographies and memoirs.

In order to understand properly Italian Judaism and the attitude of Italian Jews to Fascism, and, consequently their immigration to the United States or other countries, it is important to bear in mind that, since the time of the Emancipation, Italian Jews felt themselves to be truly Italian; they never saw themselves as a foreign body within the Italian nation but, on the contrary, they collaborated in order to create the nation, and that is why, as Dan Segre aptly affirms:

to be a Jew in Italy meant, as for many Jews in America, to feel or believe oneself to be fully integrated in the non-Jewish society, whereas for the other Jews in Europe and the Islamic world, being a Jew meant never being one hundred percent German, French or Arab, because they could not claim to be part of the host nation from its origin.”21

All this lends a particular nature to Italian Judaism and explains also why several Italian Jews who immigrated to the United States in the middle of the 1930s, mostly as a consequence of the Racial Laws Legislation in 1938, went back to Italy after War World II. To quote Tullia Zevi, one of these exiliated Jews:

I felt the impulse to go back even if I could live in America, rather to go back to Italy. The horrors of the war were only then coming to the fore-including the large-scale extermination of Jews, gypsies, and political prisoners as well as the destruction of the Jewish community. It seemed to me a question of justice- that I, who had the good fortune of surviving, should help to resurrect and rebuilt democracy in Italy. I felt and feel the duty of remember. ${ }^{22}$

Zevi and her family were exiliated to New York in 1939, where since the middle of the 1930s her brother Enzo, other relatives, and Italian Jewish friends were living. One of these Jews was the economist Fausto Pitigliani, who lived in New York from 1939 to 1948, and was the organizer and the vice-president of the New York Italian Jewish club attached to the Spanish and Portuguese Synagogue, founded to assist Italian Jewish refugees from Fascism in the United States. There is not much information about these activities, nor any written notes, but it is known that English language and culture courses were held at the synagogue in order to help Jewish immigrants integrate themselves in the new country. In addition to these activities, several Italian Jews would often meet on Sundays in a restaurant owned by an Irish lady on 72nd Street, in the Upper West Side. These meetings were held in order to provide a feeling of home for the Italian Jews, and a way to keep their Italian and Jewish identity alive. These meetings were also held at Jewish holidays, especially Pesach (Passover), so that those who were exiliated could celebrate together. During these years, the first generation of Italian Jews was a close community, often intermarrying within what was called the Italian Keillah (community). However, this aspect was quite normal not only in the first Jewish immigration, but in the first Italian Catholic one as well.

Sharing a common background and speaking the same language made the process of adapting to a new country much easier. George Sacerdote, born in New Jersey in 1945, in remembering his childhood, wrote that his parents had many Italian Jewish friends-especially his father, while his mother was also involved in the local community where they lived outside of New York City, which was made up of upper middle class WASPs:

When my family moved out from New York, started the process of American acculturation of my mother. She often told us a story about her early experiences with American culture: At one point, when she was teaching at Yale, several

${ }^{21}$ Segre Dan Vittorio, “The Emancipation of the Jews in Italy”, Path of Emancipation (Princeton, 1995), 229.

22 Zevi Tullia, Ti racconto la mia storia, 51. Unless otherwise indicated, all translations from foreign language sources are mine. 
students of her first class, took her out to a pizzeria, thinking that they were doing her a great favor. My mother had never seen such a dish before in her life-at that time in Italy, pizza was a regional dish served only in the area around Naples. During this period, my parents had lost contact with the families that had left behind in Italy. They groped connections in an America society that tried to fit them into common stereotypes. They often found themselves lumped together with other Italian immigrants, nearly all of whom were ignorant peasants from the impoverished south of Italy. As educated professional-class people from the economically advanced northern Italy, they had little in common with these working-class southern. At other times they were lumped with the recent Ashkenazi Jewish immigrants, most of whom had only recently traded the ignorance and misery of the shtetls ${ }^{23}$ of czarist Russia for the tenements and sweatshops of New York City; with these people they had even less in common. Generally they fell back on those with whom they shared an instant bond, other Italian Hebrews. In addition to the small group of Torinesi Jews whom they knew from pre-emigration time, they befriended several others. ${ }^{24}$

For Sacerdote, things were different; he did not have Italian Jewish friends when he was a child, except for the various relatives who lived in and around New York City. There was only one Italian Jewish family who lived in the same suburb as him — the Lattes—-whose son was a close friend of his older brother. He never had Italian Gentile friends, because they were too different, and, as he recalled:

I wound up having mostly German Jewish friends because I was grouped with them in school in advanced classes. The Polish Jews mostly assumed we were Catholics since they had never heard of Italian Jews. The Hebrew School teachers were even more so, and would try to force me to be a nice ignorant Polish Jew like they were. I recall being beaten up on the way home from Hebrew School by a Polish Jew in my class. ${ }^{25}$

The same experience of being rejected was shared by other second generation Italian Jews. In spring 2010, in a symposium on the perspective of "Exile, Homeland and the New World" at Columbia University, several Italian Jews born in the United States, particularly in New York City and the Metropolitan area after World War II, felt that they had all experienced the same feeling of "outsiderness" and "rejection" from both Italian-American and the American Jews, who even today refuse to believe that there could be Italian Jews.

Sacerdote remembers that when he visited the family of his Russian Jewish fiancée for the first time, her grandmother did not want to believe that he was a Jew, claiming that only Catholics exist in Italy. Sacerdote, like many other Italian Jews of his generation, considers himself totally bi-cultural, and always felt that Italian culture was a strong component of his identity. At home, as a child he used to speak Italian, French and, later on, English. Italian for him was his mother tongue: he spent many summers in Italy because his father had business interests that required annual travel there. However, among his American friends, he learned to hide his Italian background in order to avoid stereotypical questions such as: Do you know anyone in the Mafia? Or, are you really a Jew? Sacerdote married a Russian of Jewish descent, and spoke Italian with his sons until they were 15. One of them studied Italian at university. They have been to Italy with him several times, and all have read their family history. In answering my request for him to define himself, he told me that culturally speaking, he is an American Italian rather than Jewish, as "Jewish" in the United States for all intents and purposes means "Polish Jews."

Robert Zweig, author of Return to Naples (2008), an autobiographic book, which narrates in particularly his summer vacations in Naples until his Bar Mitzvah in the house of his Jewish relatives, always felt and feels that his Italian identity is prevalently cultural. Zweig was born in New York in 1955 to a Jewish Italian mother

\footnotetext{
${ }^{23}$ Shtetl was the name of a Jewish village in Eastern Europe.

${ }^{24}$ George Sacerdote, from a questionnaire that I sent him through emails in 2011.

25 Ibid.
} 
originally from Naples, and a German Jewish father-an Auschwitz survivor-who met his mother in Naples in 1945. His father was in Italy because he was looking for his sole remaining family member, a brother who was a member of the Palestinian Army near Naples. They met through a mutual friend and were married in July 1946. In December of the same year, they immigrated to New York on the Conte Biancamano, an Italian ship, thanks to the help of Gabriela's father who in those years was the head of the HIAS office in Naples, and helped the young couple to get the documentation. In 1946, the Italian quota for emigration was closed, and so it was very difficult—almost impossible—for Italians to emigrate, but Gabriela succeeded because she was married to a German citizen. Gabriela Herman, whom I interviewed in 2010, told me that she had no intention of leaving Italy, as she was very close to her family and Italian culture. However, her husband, who was from a wealthy Jewish family, lost everything and had nowhere to go, so wanted to immigrate to the United States in order to start a new life. This was the reason for her emigration. Gabriela Herman's husband had an aunt and some cousins living in Newark, New Jersey, and she had an aunt in New York City, a violinist that had played at the San Carlo Theatre in Italy, but was expelled in 1938 as a consequence of the Racial Laws and had fled to New York. Gabriela's aunt helped her to settle in New York City, and found an apartment for the young couple, first in Manhattan and later in the Bronx. As I mentioned before, several Italian Jews, despite being highly educated and qualified, adapted themselves to any kind of work, and Robert's father was one of those. As Robert told me, wrote in his book, and answered in a questionnaire that I sent him in 2011, his father had no money and accepted work as a simple clerk in a travel agency that was looking for a "hard working man.” This work allowed his father and his family to get discounted trips aboard ships and planes going to Europe. His mother was very happy with this, as she could now periodically visit her family. She went to Italy in the summer of 1948 and stayed until Robert's first brother, Richard, was born. After her return to New York, Gabriela went every year to Naples with her three children, for the entire summer.

Robert remembers that his mother always spoke with him in Italian, like she did with her other children, and being in Italy every summer helped him to become fluent in Italian. That is why, upon coming back to New York, he sometimes had some trouble speaking in English. Like his brother and sister, he attended a public school in the Bronx, where they were the only Italian Jews (even if they were only Italian Jews on his mother's side). Many of Zweig's friends were New York Jews with ancestry from Eastern Europe, and they looked at him as if he was a very different kind of Jew. In fact, many people thought that only his father was Jewish, and his mother Gabriela was just an "Italian”, presumably Catholic. “Our family confused many people,” Zweig writes,

all the time I had to explain that my mother was Italian and Jewish, a difficult concept for many to understand. I remember that when my mother was shopping, there were many salesmen who tried to ingratiate themselves to the family by turning on the charm in Yiddish—a language that my parents neither understood nor spoke. ${ }^{26}$

However, it never bothered me what I was. I did not feel particularly strange about this, since this is who my family was, but I could see the perplexity in other. On some occasions, I would hear some anti-Semitic remarks from people who thought I was “Italian”. ${ }^{27}$

I interviewed Robert Zweig's brother, Richard (born in 1948), in 2010 at his mother's house in the Bronx. He told me that when he was a child, his mother's coiffeur, an Italian immigrant from southern Italy, thought

\footnotetext{
${ }^{26}$ Zweig Robert, Return to Naples. My Italian Bar Mitzvah and Other Discoveries (New York, 2011), 159.

27 These answers come from a questionnaire that I sent in 2011 to Robert Zweig in New York City, and also from several conversations that we have had in previous years.
} 
that he was a little scemo (stupid), because when asked whether he was a Jew or an Italian, he explained that he was both. In addition, the fact that he said that he learned to speak Italian at the Jewish School in Naples when he was at kindergarten made him even more stupid in the eyes of this Italian immigrant, who hardly knew how to speak English. Their little sister, Michele, born in New York in 1962, had a similar experience due to the lack of knowledge that people had regarding the existence of Italian Jews:

It was in the midst of receiving bar mitzvah lessons, in 1968. My six year old sister was in the room when the rabbi unexpectedly asked her, “Are you American or Jewish?” At first, she was confused by the question, but after some thought, she answered with satisfaction, “I am English.” That seemed a reasonable compromise. ${ }^{28}$

The Zweig family, previously mentioned, went to Italy every summer, which is why, as he said, Robert was completely immersed in Italian popular culture. He was an avid soccer fan, watched Italian TV and movies, and knew all the popular songs, even bringing home albums to listen to in New York. Robert also remembers following many political events in Europe, particularly the Cold War which was very much in evidence in Italy at the time. He travelled a lot throughout Italy and went to many museums and archeological sites. Because of those summers in Italy, Robert felt very Italian and identified himself with Italian culture. However, this bond with Italian culture was not enough for him, or his brothers, to become friends with the other Italian immigrant children of the Bronx, because,

I found that Italian Americans did not have this same feeling. They did not have a connection to the modern Italy that I was aware of and so I often did not relate to them as Italians, but as Americans. ${ }^{29}$

It is possible to assume that Zweig, like Sacerdote, gained these cultural bonds with Italy because they received a sense of belonging from their parents and their Italian relatives, through the use of Italian language at home, habits, education, and above all, trips to Italy that reinforced their ties with their parents; this transmitted to them a love for Italy and everything Italian. Like the majority of Italian Jews who immigrated to the United States, Zweig's and Sacerdote's families were not particularly religious, but they celebrated the main Jewish holidays such as Yom Kippur and Passover, and both had Bar Mitzvahs. Zweig remembers that on the rare occasions that he spoke with his father about religion, his father sounded like an atheist, probably due to his experiences during the war, even if ultimately he began to believe in God once more.

"Like many American Jews we felt culturally Jewish but religiously less so," Zweig wrote to me in the questionnaire that I sent him. However, his memoirs are about his summer vacations in Naples and the description of his Bar Mitzvah celebration which also took place in Naples, and indicate an Italian Jewish and American identity, rather than only an American Jewish one. This complex identity is demonstrated once again by the words of the author, when he writes that:

The true feeling of my Jewishness came from the cultural and historical realities of my parents' lives, made so vivid by being in Naples, the place where they had met. Knowing that they survived the atrocity of the war, my living in Europe for long periods of time as a child—at the epicenter of the Holocaust—bore down on me with an immediacy greater than any theological beliefs I could ever envision ${ }^{30}$

This definition of a Jewish identity, or Jewishness, which, in the case of Zweig, is a personal historical, cultural, family narrative, is very common for people who belong to an ethnic group which shares an enduring

${ }^{28}$ Zweig Robert, Return to Naples. My Italian Bar Mitzvah and Other Discoveries, 159.

${ }^{29}$ Zweig Robert, questionnaire. Ibid.

30 Zweig Robert. Return to Naples. My Italian Bar Mitzvah and Other Discoveries. Ibid., 164. 
mega-narrative and historical trauma, like the Shoah. This is the reason that despite cultural elements that link the majority of the second generation of Italian Jews to their parents' country of origin, they also have ties with other American Jews. As Zweig said:

I feel more protective of my Jewish part than my Italian part, even if I would probably feel more comfortable living in Italy than in Israel. However, my American roots are very strong. My wife is Jewish of Russian and Austrian background. We have traveled to Italy many times and she loves it but she does not speak Italian. My children have also been several time to Italy especially in Naples, and, they love it as well. They studied Italian at school and speak it somewhat. My brother and sister also make frequent trips to Italy with their spouses and children, always stopped in Naples. When I received my PhD, I chose to write about Dante Alighieri because I was influenced by the people that I met in Italy who spoke of his works. My Jewish Napoletana grandmother had a recording of the Inferno (Hell) by the great Italian actor Vittorio Gassman, that I listened to over and over again as a child of ten and eleven. I continue to have great interest in Italian literature and film. I recently translated poems by Eugenio Montale and put them in an anthology of literature that I edited. $^{31}$

The stories of the second generation of Italian Jews, born in the United States, have many similarities despite the second generation having different levels of feeling "Italian", or having different relationships with a country that they have only visited or heard the history of (especially those who are of mixed marriage, where the mother or the father is not Italian). Those who are only half Italian assimilated faster in the American society, as from the very beginning they lived in a mixed culture and spoke hardly any Italian at home. It is easier to find this in the case of Italian Jews who emigrated after War World II with the intent to start a new life and, looking for better opportunities, they wanted to assimilate as fast as possible into the new land; or, as in the case of the Bedarida sisters, their swift assimilation was due to being sent by their parents to study and work in New York.

The Bedarida history is similar in some ways to the destiny of several Italian Jews who lived under Fascist regime and during World War II. Born and raised in Turin as Italian and Jewish by a wealthy intellectual family, Mirella Bedarida Shapiro attended elementary school in 1932-1935 during the Fascist regime, where, as she said to me in 2011 in New York City, she was "brainwashed with fascist doctrines, the greatness of Italy, and the power of the Italian empire.”32

She, like the majority of the Italian population, including Jews, believed all this and had a great love for her patria. However:

In September 1938, our beautiful little world collapsed as the anti-Semitic laws were enacted: Jewish children could no longer attend public schools, my father lost his job as chief surgeon of a Municipal hospital... After great efforts to get a visa to immigrate to whatever country would take us, we went to Tangier, Morocco. My parents, conscious of the trauma we (my two sisters and I) were going through, sent us to the Italian school. I guess they also thought that eventually we would go back to Italy and we would therefore have the necessary requirements to enter in an Italian university. By continuing my studies in Italian, I was able to get acquainted and enjoy Italian literature, get a better knowledge of the language and feel closer to my Italian heritage. Unfortunately, once the war ended I did not go back to Italy but immigrated to the USA. The choice to not go back to Italy was given under the suggestion of my uncle who convinced my parents to not send three girls to a destroyed, poor and dangerous country, like Italy was after War World II. My mother had some Jewish friends, which immigrated in New York before the war, and she thought they might help us, with an affidavit and to settle there, that why we went to New York.

\footnotetext{
31 Zweig Robert, questionnaire. Ibid.

32 These are the precise words that Mirella Bedarida Shapiro used in one of the many meeting that we had in the United States and Israel in the last 4 years.
} 
Life in New York City was very interesting and exciting, especially for a young girl coming from a small town in North Africa, where there was not much of a cultural life. Furthermore, during the wars years, we had been completely isolated from the rest of the world and nothing much was happening that could interest a 15, 19 year old. In New York, I followed courses at Columbia University, I met people of all nationalities and interests, I went to the best concerts, the best plays, I made friends and I was independent. I had my own money to spend as I wished, I had no supervision and could do as I pleased. I was free of my parents influence and I could take advantage and enjoy all that this dynamic city could offer. Upon my arrival in New York, I contacted several of my parents’ Italian Jewish friends, who were very nice, invited me to dinner a few times, and that was that. They were older. I wanted to meet young people, and I did, losing all my contacts with the Italian Jewish colony.

Most Jews in the States are of Eastern European descent and I ended up by making friends within this group and marrying an Ashkenazi. Nevertheless, I continued feeling very Italian. I always corresponded with my parents in Italian, spoke Italian with my sisters, (that both had married two Ashkenazi as well) and with any Italian I meet.

My husband loved Italy and, we visited Italy, very frequently. My children also travelled often to Italy and I was very happy to see their interest in my country and in my language, which they learned to read and write. ${ }^{33}$

I wanted to quote my interview with Mirella Bedarida in order to show that the concept of Jewish identity, as well identities in general, such as ethnic, cultural, social and so on, is very articulate, and is impossible to generalize and to catalogue into fixed definition.

Jewish identity throughout the centuries has been mingled with other elements, not only by ethnic elements, but, also cultural ones, in addition to historical events and relations with the non-Jewish world. This explains why the second generation of Italian Jews, like all second generation immigrants, had less difficulty in the process of Americanization, compared to their parents. Intermarriages played a crucial role in this process, as well Jewish internal mobility. After World War II, many Jews left their old, predominantly Jewish urban neighborhoods, such as the Lower East Side in New York City, which was mostly an eastern European Jewish neighborhood. In the suburbs eastern Jews had Gentiles neighbors as well as Jews from different European countries such as Italy, as reported by Sacerdote. Gina Milano, another second generation Italian Jew whose father, Franco, fled to New York in 1940 and married an Ashkenazi Jew in 1947, reports a similar experience.

In contrast to Sacerdote and Zweig, Gina spoke English at home and she was raised very American: she loves Italian culture and Italian people, but, as she said to me, her roots are American, she is an American Jew, and her husband is also an Ashkenazi Jew. Jewish life, as mentioned, changed completely in the suburbs, and the melting pot of people of different ethnicities, cultures and religions helped the process of Americanization. This created more uniformity in the second generation, which now shared a popular American culture:

In suburban public schools and on playgrounds, Jewish and non-Jewish children mixed. Jewish children developed close relations with the non-Jewish children in ways that would have been impossible for their parents and grandparents. The hostility that Jewish children had faced in the previous generation had pretty much faded. In the suburbs, Jewish children played the same games and joined the same clubs as Gentile children. Popular culture continued to be a leveling

\footnotetext{
33 During the interview that Mirella Bedarida gave me in 2011 in New York City, she also said that she feels quite comfortable and relatively satisfied with her life in New York City. New Yorkers are kind, generous, hospitable people and she made new friends. She sees old friends and she has a busy, interesting life. But, she is still not sure where she would like to finish her days. As she said: New York is still not my home; I don't feel that my roots are here. Where they are? Up to the very end of her life (105 years old), my mother Lucia, returned to Italy every year, loved to celebrate her birthdays there and we all went to Italy to be with her for such happy occasion. She really felt that was her home. There she found all the memoirs of her childhood and of her youth. Her love for that country was contagious and was transmitted to me through her genes and through her stories. I think that my father's greatest regret was not to be able to go back to Italy, to work and to live among his people. He wanted to be buried in his hometown, and he was, in the Jewish cemetery of Turin. So was my mother. My parents are back home, while I am still the wandering Jew!!!
} 
force. The move to the suburbia coincided with the first decade of television. Jewish children watched and enjoyed the same shows as their Protestant and Catholic neighbors. ${ }^{34}$

As the time goes by, second, third and, today, even fourth generations of Italian Jews look at their ancestral Italian origins as a matter of cultural identity, or folklore, as in the case of the last generation. We saw, in fact, that the feeling of Italian identity was stronger in the second generation, especially for those that had two Italians parents and were raised as Italians who lived in Italy. As Zweig affirms, Italian Americans were more assimilated into American life, compared to Italian Jews. There are various reasons for this: the first is related to the particularity of the first group of Italian Jews that were exiliated in the United States, had always planned to go back to Italy, and therefore were not too interested in Americanizing themselves.

The second reason that Italian Americans were more assimilated into American life is that Italian Jews, compared to the rest of Italian immigrants, were newcomers, since they started to flee to the United States in the early 1930s, while the rest of the Italian immigrants had been arriving since the end of 19th century. The result of this was that the idea that these immigrants had of Italy no longer corresponded to that of the immigrants who arrived almost a century later, such as the Italian Jews. Italy had become a more modern country since the first wave of Italian immigration at the end of the 19th and beginning of the 20th centuries, including an increased use of the Italian language itself, at the expense of regional dialects, especially in the North of Italy. The level of education improved and Italian people were now more educated and skilled, as in the case of Italian Jews. Furthermore, as Zweig noted, the Italian Catholic immigrants were several generations removed from their ancestral country and, from the time that he was born, they were already more "American" than him, and, people like him born in the 1950s.

\section{Conclusion}

Italian Jews that immigrated to the United States have always been different compared to the other Jewish groups, as well to the rest of the Italian Gentile immigrants. One of the differences is that the nature of Jewish identity is multifaceted and always in process, "[t]he criteria by which Jews identify themselves cover a very wide range and change over time., ${ }^{35}$

There are variations in Jewish identity that stem from peculiarities in the historical development of various communities, with the result that Jewish life is the product of historical evolution.

Italian Jewish history, as I have tried to show here, has always been unique compared to the history of the other Jewish communities, which is why we need to look at the Italian Jews, and the second generation of Italian Jewish immigrants, differently compared to the rest of the other immigrants-Italian as well Jewish. However, regarding an Italian identity and a feeling of belonging to the ancestral country, it is possible to affirm that is not the different religion that makes the difference, but rather the historical period and the reasons for immigration. The second generation of Italian Jews felt themselves culturally Italian, because their parents had just arrived in the United States and had received an Italian cultural education at home, through the use of the Italian language, the reading of Italian books and the listening to Italian music, and so on. Furthermore, the possibility that they often visited Italy helped them to maintain much more of an Italian culture and a sense of belonging compared to the rest of the immigrants.

\footnotetext{
34 Diner Asia, A New Promised Land. A History of Jews in America (New York, 2000), 96.

35 Bettin Cristina, "Identity and Identification: Jewish Youth in Italy 1870-1938”, Journal of Modern Jewish Studies, 4, n. 3 (2005): 323.
} 
Italian Jews were also a minority within a minority in the Jewish community, which consisted predominantly of Eastern European Jews, or Sephardim and Oriental Jews. However, despite the feeling of been considered "weird" or "different," by those Jews, Italian Jewish immigrants shared with them historical narratives and tragedies such as the Holocaust, which forged closer links between them than with the non-Jewish Italians; we see evidence of this in the second generation of Italian Jews, who often intermarried with other Jews, mostly of Ashkenazi descent.

Nevertheless, what made the second generation of Italian Jews unique in comparison with other Jews was their sense of cultural belonging and pride in having some form of Italian origin. No other Jews who had immigrated to the States—such as Polish or German and so on—felt such a feeling for the country where their parents were born. On the contrary, because of the discrimination, persecution, and genocide that their families experienced, many European Jews who immigrated to the United States disliked their ancestral country. This explains why it is important in a study of identities, particularly Jewish identity, to take into consideration the historical context and the Gentile society in which it is located and with which it interacts.

\section{References}

Bedarida, S. L. (2002). "Reflection on an Italian Jewish Life”, the most ancient of minorities-The Jews of Italy. Westport: Greenwood Press.

Bettin, C. (2005). Identity and identification: Jewish youth in Italy 1870-1938. Journal of Modern Jewish Studies, 4(3), 323. Oxford: University of Oxford Press.

Bettin, C. (2010). Italian Jews from emancipation to racial laws. New York: Palgrave Macmillan.

Bettin, C. (2011). The role of holy place in memory and nostalgia: The immigration of Italian Jews to Israel before and after WWII. Forum Italicum, 45(2), 360. Stony Brook: Stony Brook University Press.

Cantoni, G. (2000). From Milano to New York by way of hell: Fascism and the Odyssey of a young Italian Jew. Lincoln: Writers Club Press.

Diner, A. (2000). A new promised land. A history of Jews in America. New York: Oxford University Press.

Foa, V. (1993). In Stille Alexander, benevolence and betrayal: Five Italian Jewish families under fascism. London: Penguin, 95.

Gitelman, Z. (1998). The decline of the diaspora Jewish nation: Boundaries, content and Jewish identity. Jewish Social Studies, 4(2).

Glazer, N., \& Daniel, M. (1963). Beyond the melting pot. Cambridge, Mass: MIT Press.

Goldberg, D. (1993). The culture of identities. In Goldberg and Krauzs (Eds.), Jewish Identity (p. 1). Philadelphia: Temple University Press.

Heilman, S. (2003). American Jews and community: A spectrum of possibilities. Contemporary Jewry, 24(1), 51.

Hermann, S. (1989). Jewish identity. New Brunswick, NJ: Transation Publisher.

Levi, P. (1985). The periodic table. Great Britain: Michael Joseph Ltd.

Pekelis, C. (2004). My version of the facts. Evanston: Northwestern University Press.

Sacerdote, G. (Ed.). (2007). Remembrance and renewal-500 years of European wars and politics and their impact on five Hebrew families. USA.

Segre, D. (1995). The emancipation of the Jews in Italy. In Katznelson and Birbaum (Eds.), Path of emancipation (p. 229). Princeton, N.J.: Princeton University Press.

Servi, M. E. (1995). Child of the ghetto-Coming of age in fascist Italy: 1926-1946. A memoir. Croton-on-Hudson: Giro Press.

Showstack, G. (1990). Perspectives in the study of American Jewish ethnicity. Contemporary Jewry, 11(1), 88.

Webber, J. (1994). “Continuity and discontinuity,” and “Modern Jewish identity”, Jewish Identity in the New Europe. London and Washington: Littman Library of Jewish Civilization.

Weber, M. (1922). The origins of ethnic groups. In J. Hutchinson and A. Smith (Eds.), Ethnicity (p. 35). Oxford-NY: Oxford University Press.

Wsevold, W. I. (1974). Definition of ethnicity. Ethnicity, 1(2), 111-174.

Zevi, T. (2007). Ti Racconto la Mia Storia. Milano: Rizzoli.

Zweig, R. (2008). Return to Naples. Fort Lee, N.J.: Barricade. 